\title{
Author Correction: Lead compounds for the development of SARS-CoV-2 3CL protease inhibitors
}

Sho Iketani (D), Farhad Forouhar, Hengrui Liu (D), Seo Jung Hong, Fang-Yu Lin (1D, Manoj S. Nair (D), Arie Zask,

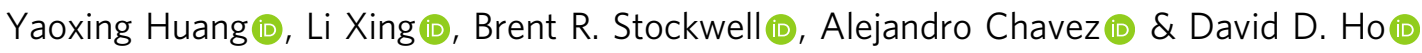

Correction to: Nature Communications https://doi.org/10.1038/s41467-021-22362-2, published online 1 April 2021.

The original version of this Article omitted the following from the Acknowledgements: Part of the research was conducted at the Northeastern Collaborative Access Team beamlines, which are funded by the National Institute of General Medical Sciences from the National Institutes of Health (P30 GM124165). This has now been corrected in both the PDF and HTML versions of the Article.

Published online: 05 May 2021

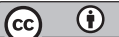

Open Access This article is licensed under a Creative Commons Attribution 4.0 International License, which permits use, sharing, adaptation, distribution and reproduction in any medium or format, as long as you give appropriate credit to the original author(s) and the source, provide a link to the Creative Commons license, and indicate if changes were made. The images or other third party material in this article are included in the article's Creative Commons license, unless indicated otherwise in a credit line to the material. If material is not included in the article's Creative Commons license and your intended use is not permitted by statutory regulation or exceeds the permitted use, you will need to obtain permission directly from the copyright holder. To view a copy of this license, visit http://creativecommons.org/licenses/by/4.0/.

(C) The Author(s) 2021 